\title{
The Role of Motion Verbs in Conveying Path-Related Information in English and Slovene Fictive Motion Expressions
}

\begin{abstract}
The paper presents a study on fictive motion (FM) uses of motion verbs in English and Slovene from the point of view of conveying path-related information. An FM expression describes a static scene in terms of motion (e.g. The road weaves through a range of hills). Motion verbs in FM uses do not describe actual motion events, but may refer to certain properties of the path by virtue of their meanings. English and Slovene FM expressions exhibit different behaviours in this respect. Many English verbs display meaning components that can be metonymically mapped onto the properties of the path. The meanings of Slovene verbs are less specific, so that such properties need to be expressed verb-externally in Slovene FM expressions.
\end{abstract}

Keywords: fictive motion; motion verbs; manner of motion; path; metonymy; metonymic mapping

\section{Vloga glagolov premikanja pri opisu poti $\mathbf{v}$ angleških in slovenskih izrazih fiktivnega gibanja}

POVZETEK

V članku je predstavljena študija glagolov premikanja v angleških in slovenskih izrazih fiktivnega gibanja z vidika informacij, ki jih ti glagoli posredujejo o poti premikanja. Izraz fiktivnega gibanja opisuje statični prizor na podlagi gibanja oziroma premikanja (npr. Cesta vijuga med hribi). Glagoli premikanja v tovrstni rabi ne izražajo dejanskega premikanja, vendar se lahko na podlagi svojega pomena nanašajo na nekatere vidike poti. Angleški in slovenski izrazi fiktivnega gibanja se v tem pogledu vedejo različno. Mnogo angleških glagolov vsebuje pomenske komponente, ki omogočajo metonimično preslikavo na določene lastnosti poti. Pomeni slovenskih glagolov so manj specifični, zaradi česar se v slovenskih izrazih fiktivnega gibanja za opis poti uporabljajo druga, tj. neglagolska sredstva.

Ključne besede: fiktivno gibanje; glagoli premikanja; način premikanja; pot; metonimija; metonimična preslikava 


\section{The Role of Motion Verbs in Conveying Path-Related Information in English and Slovene Fictive Motion Expressions}

\section{Introduction}

Fictive motion ${ }^{1}$ is a construal of a static scene in terms of motion. Sentence (1a) below communicates a stationary situation by describing a scene that, owing to the verb lead, invites motion: our eyes mentally scan an imaginary path leading onto the terrace. Similarly, there is an imaginary entity moving along the road in (1b).

(1) a) The French windows lead out onto a wide shady terrace. (CALD)

b) The road weaves through a range of hills. (OALD)

Sentence (1b) contains a motion verb commonly found in real (i.e. actual) motion sentences like He hurried on, weaving through the crowd (OALD). Nevertheless, weave in (1b) cannot express motion since a static scene with a stationary trajector $(\mathrm{TR})^{2}$ is described. Rather, it provides information about the TR: the manner component of its meaning is mapped onto the shape of the road.

The paper presents a study focusing on uses exemplified by weave, above. It examines the use of motion verbs conveying path-related information ${ }^{3}$ in English and Slovene FM expressions. The study is presented in the second half of the paper. The two introductory sections are devoted to the theoretical aspects of fictive motion and its linguistic manifestation.

\section{Understanding Fictive Motion}

The processing of FM sentences involves "mentally simulated motion" (Matlock 2004a, 2004b): the conceptualizer (i.e. the language user) mentally simulates visual scanning in (1a) and movement in (1b). Motion is imposed on the scene subjectively; the conceptualizer is neither part of the objective scene nor moving through it (Langacker 2000,6).

As observed by Talmy (2000, 104), "languages systematically and extensively refer to stationary circumstances with forms and constructions whose basic reference is motion.” Representations of stationariness in terms of motion are much more common than representations of motion in terms of stationariness - an asymmetry reflecting a "cognitive bias toward dynamism" $(2000,171)$.

In his ground-breaking work on nonveridical phenomena, Talmy (2000) subsumes fictive motion under "general fictivity", a cognitive pattern characterized by "discrepancy between two different cognitive representations of the same entity, where one of the representations is assessed as being more veridical than the other" (Talmy 2000, 100). The discrepant representations as

Also referred to as abstract/subjective/virtual motion.

The carrier of the relation in a spatial scene; the entity (stationary or in motion) whose location is described in relation to the landmark (LM), a reference point entity (cf. Langacker 1987, 217ff.).

Path-related information is used as a cover term to refer to the properties of the TR in a static scene. The path - TR connection is obvious, since the TR either coincides with or in some way accommodates the imaginary path travelled by a fictively moving entity. 
well as the assessment of their veridicality are produced by distinct cognitive subsystems within the cognition of a single individual. Talmy proposes the term "factive" to designate the more veridical representation and the term "fictive" to designate the less veridical one, pointing out that the ascribed degree of veridicality is the result of a cognitive assessment rather than a reflection of objective (un) reality.

Fictive motion is a manifestation of "fictive X" (Talmy 2000, 101), a category comprising any possible fictive representation (fictive presence, absence, change, etc.) within the general fictivity pattern. There are several dimensions along which discrepancies of the factive/fictive opposition can be identified. Relevant to the present study is the "state of motion", where the more veridical, factive representation involves stationariness and the less veridical, fictive one motion. The former is based on belief and the latter on linguistic form. For illustration, our knowledge of the world tells us that sentence (1b) describes a factively static scene; it is our belief that roads do not move in space-time. Nevertheless, the presence of a motion verb together with a directional PP evokes a fictive, nonveridical representation of something in motion. The sentence exhibits a "linguistic pattern in which the literal meaning of a sentence ascribes motion to a referent that one otherwise normally believes to be stationary" (Talmy 2000, 101). The degree to which motion is experienced may vary across speakers.

In line with the view that language mirrors human conceptualization and that cognitive processes are largely based on the principles of visual perception (cf. Jackendoff 1994), Talmy (2000, 102f.) points out the analogy between linguistic and visual manifestations of fictive motion. If a visual scene allows two simultaneous representations, the one perceived in terms of stationariness will be assessed as the more palpable, factive one, and the one perceived in terms of motion as the less palpable, fictive one. Thus, a sense of motion is ascribed to a scene that one otherwise normally sees to be stationary. There is an obvious parallel between the believing/inferring ${ }^{4}$ opposition characterizing fictive-motion sentences, and the seeing/sensing opposition characterizing visual scenes.

Fictive motion is also interpreted in terms of conceptual blending (or conceptual integration), a cognitive operation of integrating two or more input mental spaces ${ }^{5}$ into a new, blended space with an emergent structure of its own (Fauconnier 1997; Fauconnier and Turner 2002). Mapping between the elements of the input spaces makes it possible to convey immobility and motion at the same time. For illustration, the subject (the road) in (1b) above evokes an immobility space and the predicate (weaves through a range of hills) a motion space. The elements of the immobility space thus include a stationary TR (the road). The elements of the motion space include a moving TR and its trajectory (i.e. the path along which it moves). Cross-space mapping connects the trajectory from the motion space to the road from the immobility space. The trajectory and the road project onto the same single element in the blended space: the stationary TR emerges as a path designated for a moving TR.

According to Jiménez Martínez-Losa (2007, 564f.), the conceptualization of fictive motion relies on the MOTION metaphor, a conceptual metaphoric shift between a factive motion event as the source domain and a fictive motion event as the target domain. Jiménez Martínez-Losa notes that fictive motion events have no parallel in reality, and are therefore more abstract than factive motion events. The direction of the shift, namely from factive motion to fictive motion, thus accords with the fact that metaphor typically involves the mapping of elements belonging to a

Used in the sense 'inferring the meaning as determined by the language system'.

For the theory of mental spaces see Fauconnier (1994). 
concrete domain onto elements belonging to an abstract domain. Moreover, the trajector of a fictive motion event is conceptualized as a moving entity, i.e. like the trajector of a factive motion event, which accords with the view that metaphor is based on the identity of relations (cf. Lakoff 1987; Lakoff and Johnson 2003). Last but not least, Jiménez Martínez-Losa points out that the conceptualization of fictive motion foregrounds the path that the trajector of a factive motion event would follow (e.g. through a range of hills in (1b)). She argues for an underlying metonymic relationship where the motion along the path activates the path of motion (MOTION ALONG A PATH FOR PATH metonymy), or rather, where the conceptualization of a path naturally results from the action of motion along the path (ACTION FOR RESULT metonymy) (ibid., 565f.). In sum, the conceptualization of fictive motion involves the MOTION metaphor motivated by THE ACTION FOR RESULT metonymy.

Recognizing metonymy in fictive motion is of particular relevance to our paper, because metonymic relations can be observed in FM uses of motion verbs, especially those expressing the manner of motion. Matlock (2004b, 11-12) discusses crawl, race and stagger from the point of view of information they can convey about the TR in a static scene (representing the path in the fictive representation). She argues that a highway that crawls through the city is construed differently from a highway that races through the city, the former being associated with slow motion and the latter with fast motion. Similarly, a footpath that staggers from point A to point $\mathrm{B}$ is likely to be conceptualized in terms of several sharp bends, associated with the particular way of walking denoted by stagger. Such metonymic inferences based on associations demonstrate that metonymy is more than just a "stand-for" relation (cf. Barcelona 2011; Langacker 2000; Panther and Thornburg 2005).

\section{FM Expressions}

Fictive motion manifests itself in language in several ways. Talmy $(2000,105)$ identifies a set of conceptual features whose values, or rather combinations of these values, distinguish different categories of fictive motion. For illustration, the FM construals below differ with regard to three principal features: +/- obligatoriness of factive motion, +/- observer-based fictive effect, +/factiveness of the fictively moving entity.

(2) a) The fence goes from the plateau to the valley. (Talmy 2000, 138)

b) I sat in the car and watched the scenery rush past me. (Talmy 2000, 132)

In (2a), no element needs to actually move, the fictive effect does not depend on the observer (i.e. it is observer-neutral), and the fictively moving entity exists only in the observer's imagination (i.e. it is fictive). In (2b), a factively moving observer is crucial for the fictive effect, the fictive effect is obviously observer-based, and the fictively moving entity exists in the real world (i.e. it is factive).

According to Talmy's classification of FM categories, the two FM expressions under (2) represent a "coextension path" (Talmy 2000, 138f.) and "frame-relative motion" (Talmy 2000,130_ 34) respectively. With few exceptions, the categories are referred to as "paths" (coextension paths, orientation paths, radiation paths, access paths, etc.), reflecting the fact that the path is foregrounded in fictive motion and that an FM expression essentially depicts the (factive, stationary) TR - LM arrangement in terms of a path. For example, in a coextension path (e.g. (2a)) the path runs along the TR's extent whereas in an access path (e.g. The bakery is across the street from the bank (Talmy 2000, 137)), the TR represents the endpoint on the path. 
We will focus on coextension paths because we are interested in the relation between the manner of motion and the properties of the factive TR. If the manner of motion evokes information about the path, it is reasonable to limit the study to cases where properties of the path can be understood as properties of the TR. This condition is met by coextension paths, which involve a path moving along/over/across a spatially extended object (TR).

A coextension path is defined as a "depiction of form, orientation, or location of a spatially extended object in terms of a path over the object's extent" (Talmy 2000, 138). The path is not necessarily linear, and exactly what is imagined as moving along the path is not specified: Talmy points out it can be an observer, ${ }^{6}$ the focus of one's attention, ${ }^{7}$ or the object itself. ${ }^{8}$ This goes hand in hand with Matlock's (2004a, 1396) observation that the processing of an FM sentence combines several types of simulations. Nevertheless, although these simulations are not mutually exclusive, they are not equally salient. For example, fictive motion along an object that is not normally perceived as travelable by humans (e.g. a fence, as opposed to a road) is more likely to be simulated in terms of sequential mental scanning than in terms of an imagined traveller (cf. also Rojo and Valenzuela 2010, 255).

TRs in coextension path expressions are spatially extended entities that need not be inherently long, but must be at least conceptually extendable (Matlock 2004b, 7). For illustration, the sentences below differ in acceptability because the TR in (3b) does not readily admit of a conceptualization in terms of linear extension.

(3) a) The table goes from the kitchen wall to the sliding glass door. (Matlock 2004b, 7)

b) ?? The hoola hoop runs from the door to the couch. (Matlock 2004b, 8)

The TR is usually associated with linearity and horizontal extension; nevertheless, certain types of TRs are typically associated with vertical extension (e.g. tall buildings and landscape features like mountains and cliffs). Moreover, some TRs can be construed in different ways through different types of verbs (Egorova, Tenbrink, and Purves 2018, 14). Egorova, Tenbrink, and Purves present mountain ridges as a case in point, demonstrating that they can be construed as being linear and having a complex shape (4a), as horizontally extended without a complex shape (4b), or as vertically extended (4c):

(4) a) A slender scimitar-shaped ridge curved upwards.

b) To the north an almost horizontal ridge runs west over Whymper, Croz ...

c) Glancing above, the ridge soared in a series of ice towers.

(Egorova, Tenbrink, and Purves 2018, 14)

Each of the above construals arises from the semantics of a different type of verb. The verb curve encodes a change in direction; the verb run encodes motion along a TR of non-specified shape; the verb soar encodes upward vertical motion combined with manner ('rise quickly'). The manner of motion generally conveyed by run appears to be suppressed in fictive motion (cf. Matsumoto 1996;

6 Cf. the local path/frame (Matsumoto 1996, Talmy 2000). With a moving observer, the scope of attention is a "local" one: the observer's immediate field of view changes all the time.

7 Cf. the global path/frame (Matsumoto 1996, Talmy 2000). With a stationary observer, the scope of attention is a "global" one: the observer moves the focus of attention by visually scanning along the path, but his/her field of view remains unchanged.

8 Imagined as if "advancing along its own axis" (Talmy 2000: 138). 
see also the discussion below). The most relevant to our study are FM expressions like (4c) because the manner-of-motion component of the verb's meaning indirectly conveys information about some property of the TR: with the verb soar, the ridge is construed as ascending at a steep angle.

In terms of syntax, a typical coextension path sentence displays the structure $S+P+A$ :

(5) This road goes to Birmingham. (CALD)

The subject represents the TR and the adjunct the LM. The adjunct is realized by a PP expressing direction. The predicator contains a motion verb. It should be noted at this point that none of the constituents corresponds to a trajectory (i.e. path) since the sentence (factively) describes a static scene. It is only the fictive representation of the sentence that involves motion. There, the subject NP is conceived of as the trajectory (or the entity along/over which the trajectory runs) of an imaginary TR that has no syntactic realization.

Needless to say, there are variations on the basic pattern (cf. Matlock 2004b). For example, (6a) below displays a set of two LMs. In (6b), the LM is represented by a direct object. The LM remains implicit in (6c), where the verb is followed by a directional particle and an adjunct of extent. In (6d), the verb occurs without any complementation because the relative orientations of the distributaries are inferable from its lexical meaning.

(6) a) A huge crack went from the top to the bottom of the wall. (CALD)

b) Turn left where the lane meets the main road. (CALD)

c) The tree's roots go down three metres. (CALD)

d) A sample of water was taken from the point where the river bifurcates. (CALD)

Last but not least, the verb in the predicator need not be an actual motion verb (see (6b) and (6d) above), or, as noted by Ruppenhofer $(2006,310$, fn. 4), "not all fictive motion uses are productively formed from verbs of (actual) motion."

In his seminal study on English and Japanese motion verbs, Matsumoto (1996) proposes two conditions that govern the use of FM expressions involving coextension paths. The conditions read as follows:

a. The path condition: Some property of the path of motion must be expressed.

b. The manner condition: No property of the manner of motion can be expressed unless it is used to represent some correlated property of the path.

(Matsumoto 1996, 194)

The path condition states that an FM expression is acceptable only if it includes information about the shape or some other aspect of the path. For illustration (adapted from Matsumoto 1996: 194):

(7) a) The road began to ascend.

b) *The road began to run.

c) The road began to run straight.

Ruppenhofer mentions taper and jut as examples of "specifically fictive" verbs, i.e. non-motion verbs occurring specifically in FM expressions (e.g. Turn left where the road tapers (off) into a track. (CALD)). 
The path condition makes relevant the distinction between path-conflating verbs like ascend and manner-conflating (or manner-of-motion) verbs like run. In (7a), it is evident from the meaning of the verb that the road is positioned on a slope. Conversely, run in (7b) conveys no path-related information. Sentence (7c) is acceptable owing to an adverb whose meaning is correlated with the shape of the path.

The manner condition imposes restrictions on the use of manner-of-motion verbs in FM constructions. As the term implies, manner-of-motion verbs describe the mode in which an object moves along its path. Sometimes the manner of motion evokes a property that is relevant to the path (zigzagging, for example, evokes a Z-shape). The manner condition precludes any uses of manner-of-motion verbs where the verb cannot be interpreted as (indirectly) conveying some path-related information. For illustration (adapted from Matsumoto 1996, 194):

(8) The road wanders $/ *$ walks through the park.

The verb wander can represent fictive motion because its meaning evokes some kind of irregular path shape corresponding to walking around without any clear purpose or direction. Conversely, no path feature is evoked by walk, rendering the sentence unacceptable.

A slight problem is now presented by (7c) above. The sentence is acceptable although the verb run does not evoke any path-related property:

(9) The road began to run straight. (= 7c)

Matsumoto $(1996,200)$ proposes that the sentence is not in conflict with the manner condition because in the case of run, the semantic component of manner is suppressed in FM expressions. He also observes that run is the only manner-of-motion verb exhibiting this type of behaviour. ${ }^{10}$

The path and manner conditions introduced by Matsumoto (1996) represent a major contribution to the field and are extensively referenced in the literature. Waliński (2015) argues for a third condition, the so-called instrument condition stating that "no property of motion instrument can be expressed in a coextension path, unless it is used to represent some specifically correlated property of the path" (Waliński 2015, 98). The condition, supported by the results of a corpusbased study (Waliński 2015), precludes instrument-conflating motion verbs (i.e. motion verbs whose meanings entail an instrument of motion; e.g. drive, pedal, ride) from structuring fictive motion. For illustration (cf. Waliński 2015, 90):

(10) This road goes/*drives to London.

Nevertheless, Waliński at the same time admits that since instrument and motion form a semantic cline, the instrument condition partly overlaps with Matsumoto's manner condition. As a matter of fact, Matsumoto (1996: 190) subsumes the type of vehicle used in motion under the aspects of manner.

\section{The Aim of the Study and Methodology}

The aim of the study was to examine the role of motion verbs in English and Slovene FM expressions from the point of view of their potential to convey path-related information. With

10 The same holds for its Japanese counterpart (ibid.). This, however, is not universal. See, for example, Takemoto (2010) for a comparison with French and German. 
a view to identifying similarities/differences between the two languages, the following research questions were formulated:

i) Which types of motion verbs are employed by English and Slovene FM expressions to convey path-related information?

ii) Which properties can be expressed by these verbs and how?

Relevant FM expressions were searched in language corpora by using the Sketch Engine corpus tool. The goal was not to perform a quantitative analysis but to identify the scope of motion verbs in FM uses. The following corpora were used: the British National Corpus (BNC), the British English Corpus (ukWaC) and the English Web Corpus from the TenTen Corpus Family (enTenTen) for English, and the Slovenian Reference Corpus (FidaPLUS v2) and the Slovenian Web Corpus from the TenTen Corpus Family (slTenTen) for Slovene.

The corpora were queried for verbs that collocate with nouns representing TRs in coextension paths. The selection of nouns was partly based on Egorova, Tenbrink, and Purves' (2018) research into fictive motion in the context of mountaineering. Drawing upon their list of 10 most frequent landscape terms occurring in FM expressions (Egorova, Tenbrink, and Purves 2018, 13), the following four nouns were selected: mountain (Slo: gora) and slope (Slo: pobočje) as entities associated with vertical extension, ridge (Slo: greben) as an entity that can be associated with both vertical and horizontal extension, as well as with linearity and complex shape (see the previous section), and valley (Slo: dolina) as an entity associated with linearity and horizontal extension but also allowing a construal in terms of vertical extension (Egorova, Tenbrink, and Purves 2018, 15). Path (Slo: steza) and road (Slo: cesta) were added to the list as entities associated with linearity or a complex shape, and differing with regard to the mode of travel.

With five corpora used, there were five queries for each noun. Each individual query generated a list of verbal collocates arranged according to the collocation strength. The maximum number was set at 200 (relevant for nouns with a high number of collocates). The list was examined manually to extract the verbs whose meanings conflate motion with path/manner. The verbs whose meanings do not evoke any correlated path properties (e.g. run) and any uses representing FM categories other than coextension paths (e.g. surround used in an advent path (cf. Talmy 2000, 135) or poke in a demonstrative path (Talmy 2000, 109)) were not included. Several collocations had to be discarded because they did not represent the targeted subject + verb structures but complex NPs (e.g. ridge scrambling, road humps), or the noun was not used with the targeted meaning (e.g. English path, Slovene greben). For each language, a final list was compiled comprising all verbs from the individual lists (three for English, two for Slovene) that were recognized as relevant to the study.

\section{Results}

Among the collocations generated by the corpora search, the following noun + verb combinations were identified as representing FM uses of motion verbs conveying path-related information.

1. mountain (En) / gora (Slo)

a) Vertical motion

English: climb, descend, dip, drop, fall, plunge, rise, sink, soar, tumble

Slovene: ${ }^{11}$ dvigati/dvigovati/dvigniti se, spuščati se, vzdigovati se, vzpenjati se

11 The English translations are given in Table 1. 
b) Horizontal motion

English: roll, sweep

Slovene: --

2. (mountain) ridge (En) / (gorski) greben (Slo)

a) Vertical motion

English: ascend, climb, descend, drop, fall, rise

Slovene: dvigati/dvigovati/dvigniti se, spuščati/spustiti se, vzpeti se

b) Horizontal motion

English: curve, sweep

Slovene: obrniti se, valoviti, viti se

3. slope (En) / pobočje (Slo)

a) Vertical motion

English: ascend, climb, descend, drop, fall, plunge, rise

Slovene: dvigati/dvigovati se, padati, spuščati/spustiti se, vzpenjati se

b) Horizontal motion

English: ease, roll, slip, sweep, turn, wind

Slovene: --

4. valley (En) / dolina (Slo)

a) Vertical motion

English: climb, descend, drop, fall, plunge, rise

Slovene: dvigati/dvigniti se, spuščati/spustiti se

b) Horizontal motion

English: flow, roll, sweep, turn, wind

Slovene: viti se, zaviti

5. path (En) / steza (Slo)

a) Vertical motion

English: ascend, climb, descend, dip, drop, fall, rise

Slovene: dvigati/dvigniti se, spuščati/spustiti se, vzpenjati/vzpeti se

b) Horizontal motion

English: criss-cross, curve, ease, hop, loop, meander, roll, snake, sweep, swing, turn, twist, undulate, veer, wander, weave, wind, zigzag

Slovene: cikcakati, obrniti se, vijugati, viti se, zaviti

6. $\operatorname{road}(\mathrm{En}) /$ cesta (Slo)

a) Vertical motion

English: ascend, climb, descend, dip, drop, fall, rise

Slovene: dvigati/dvigovati/dvigniti se, povzpeti se, spuščati/spustiti se, vzpenjati/vzpeti se 
b) Horizontal motion

English: criss-cross, curve, loop, meander, snake, sweep, swing, turn, twist, undulate, veer, weave, wind

Slovene: obrniti se, vijugati, viti se, zavijati/zaviti

The data are summarized in the table below, with the verbs classified into five groups:

i) directional verbs encoding upward vertical motion (e.g. rise)

ii) directional verbs encoding downward vertical motion (e.g. fall)

iii) directional verbs encoding a change of direction and/or motion along a curved path (e.g. curve)

iv) manner-of-motion verbs encoding motion along a path of complex shape (e.g. zigzag)

v) manner-of-motion verbs encoding motion along a path of non-specified shape (e.g. hop)

TABLE 1. Motion verbs conveying path-related information

\begin{tabular}{|l|l|l|}
\hline & English & Slovene \\
\hline Upward motion & ascend, climb, rise, soar & $\begin{array}{l}\text { dvigati/dvigovati/dvigniti } \\
\text { se ('rise'), povzpeti se } \\
\text { ('ascend, climb'), vzdigovati } \\
\text { se ('rise'), vzpenjati/vzpeti } \\
\text { se ('ascend, climb') }\end{array}$ \\
\hline Downward motion & $\begin{array}{l}\text { descend, dip, drop, fall, } \\
\text { plunge, sink, topple, tumble }\end{array}$ & $\begin{array}{l}\text { padati ('fall'), spuščati/ } \\
\text { spustiti se ('descend') }\end{array}$ \\
\hline $\begin{array}{l}\text { Change of direction, curved } \\
\text { path }\end{array}$ & $\begin{array}{l}\text { curve, loop, turn, veer, sweep, } \\
\text { swing }\end{array}$ & $\begin{array}{l}\text { obrniti se ('turn'), zavijati/ } \\
\text { zaviti ('turn') }\end{array}$ \\
\hline $\begin{array}{l}\text { Manner + complex shape } \\
\text { criss-cross, meander, snake, } \\
\text { twist, undulate, weave, wind, } \\
\text { zigzag }\end{array}$ & $\begin{array}{l}\text { cikcakati ('zigzag'), valoviti } \\
\text { ('undulate'), vijugati } \\
\text { ('weave'), viti se ('wind') }\end{array}$ \\
\hline $\begin{array}{l}\text { Manner + non-specified } \\
\text { shape }\end{array}$ & $\begin{array}{l}\text { ease, flow, hop, roll, slip, } \\
\text { wander }\end{array}$ & -- \\
\hline
\end{tabular}

\section{Discussion}

The results demonstrate a discrepancy between English and Slovene FM expressions in the use of motion verbs that convey path-related information. The English verbs outnumber the Slovene ones ${ }^{12}$ for two reasons. First, quite a few English verbs do not have distinct Slovene equivalents, even in actual motion uses, and share an equivalent with a relatively general meaning (e.g. meander, snake, twist, weave, wind $\rightarrow$ viti selvijugati). Second, some of them have Slovene equivalents that resist fictive motion uses (e.g. climb $\rightarrow$ plezati; plunge $\rightarrow$ planiti, strmoglaviti; topple $\rightarrow$ prevrniti se; hop $\rightarrow$ skakljati).

\footnotetext{
12 It should be noted that the Slovene set of upward motion verbs basically comprises lexical aspectual variants of only two verbs:
} dvigniti se 'rise' and vzpeti se 'ascend' (see Table 1). 
The inventory of English verbs includes verbs whose meanings display semantic components pertaining to some other aspects of motion. For illustration, the verb plunge designates a sudden movement. This component of meaning translates into a property of the path (steepness in our case; see the discussion below) that can only be expressed verb-externally in Slovene. Compare:

(11) a) High mountains plunge into glittering lakes, creating almost fjord-like scenery. (ukWaC)

b) Visoke gore [...] strmo padajo proti Tihemu oceanu. (FidaPLUS v2) 'High mountains [...] fall steeply towards the Pacific Ocean.'

The verbs presented in Table 1 primarily convey information about the direction of movement or the path-shape related manner of motion (the exception being verbs encoding motion along a path of non-specified shape, which will be treated separately). Nevertheless, as demonstrated by plunge above, some verbs at the same time encode information about speed. Among the verbs encoding direction or path shape, the following ones display a speed component in their semantics: soar ('rise quickly'), plunge ('move or fall suddenly'), tumble ('fall quickly and without control'), sweep ('move quickly and powerfully'), meander ('move slowly and not in a straight line'), weave ('move quickly and change direction often'), and Slovene vijugati ('change direction repeatedly and quickly'). ${ }^{13}$ In tumble, the speed component combines with that of unsteadiness and loss of control.

In FM expressions, however, where no actual motion is involved, the speed component obviously cannot express speed but is mapped onto some path feature associated with speed. In the case of vertical motion this feature appears to be the path's gradient, a connection deriving from the observation that the steeper the incline, the shorter the path connecting two extreme positions and, crucially, the shorter the time of travel. The unsteadiness component observed in tumble is mapped onto the very height of the vertically extended entity, a manifestation of the fact that the taller a vertically extended object, the more likely it will lose balance and fall over. The physical properties of mountains thus make it possible for the noun mountain to collocate with tumble.

(12) Tall green snow-capped mountains tumble majestically into the clear blue ocean waters that make up the Inlet system. (enTenTen)

With manner-of-motion verbs the speed component can be mapped onto the specifics of the path shape. For example, the verbs weave and wind express motion along the same general complexshape path - a path that is not straight but has several curves, twists and bends. Nonetheless, a weaving path seems to be visualized as having more changes of direction and sharper bends than a winding path, although the two designations can be used interchangeably. The same can be said of the Slovene verbs vijugati ${ }^{14}$ and viti se, respectively. Again, a connection with speed can be established: the higher the number of curves in a sinusoid-shaped path, the faster one must travel so as to cover a given distance in a given time.

The speed component could also play a role in FM uses of sweep, although the change of direction (13a) or the curved shape of landscape features $(13 \mathrm{~b})^{15}$ is more likely to be metaphorically related to the curve involved in a basic sweeping movement - which, in turn, is a quick and forceful one.

13 The meanings given in brackets are based on dictionary definitions (CALD, COBUILD, OALD, SSKJ).

14 'To quickly, continuously change the direction of travel' (SSKJ).

15 (Of landscape) 'to form a long smooth curve' (OALD). 
(13) a) The path sweeps left and is joined by another path coming in from the left. (ukWaC)

b) Beyond lay snowcapped mountains and mist-filled valleys sweeping to infinity. (enTenTen)

Of particular interest is the small set of verbs expressing manner of motion without reference to any specific path shape. Wander represents a borderline case here, since its meaning ${ }^{16}$ still evokes some kind of irregular shape. The verbs hop and slip describe a quick, sudden, effortless movement, the verb ease ${ }^{17}$ a slow, gentle, careful motion, flow a slow, steady motion, roll a smooth, effortless motion. Meaning components like the effortlessness and smoothness of motion are mappable onto features pertaining to terrain configuration. The connection is obvious: the less difficult the terrain, the smoother/easier motion over it.

For example:

(14) a) The coast path hops through the car park to follow the lip of Hazelphron Cliff, which terminates at a substantial, wind-swept headland some 600 yards further on. (ukWaC)

b) The grassy slope slipped away a bit easier on the other side, and the running figure was easily visible. (enTenTen)

c) A second sloping off, and the path eases its way up this pleasant grass slope with a glorious view of Loch Cluanie. ( $\mathrm{ukWaC}$ )

d) The Green Bridge now spans the road and as you walk across it, you would hardly know you were on a bridge at all as the park path rolls across it without interruption. (ukWaC)

To what an extent this type of mapping is actually involved is open to interpretation. It can be supported by an additional element in the sentence structure such as a bit easier in (14b) or without interruption in (14d). Nevertheless, an interplay between the effort and speed components is also possible (cf. (14a), where hop suggests that the path leaves the car park quickly, meaning that the segment running through the car park must be relatively short), or there may be a metaphor underlying the expression. For example, the uses of flow are metaphorically related to the movement of bodies of water like streams and rivers (15a): ${ }^{18}$

(15) a) Finally, we reached the ridge, and there, in front of us, was Tuscany, secret valleys flowing from the peaks. (ukWaC)

b) Even an hour away from landing, I'd look out the window and see nothing but mountains rolling one after the other like a stormy ocean of rock. (enTenTen)

In (15b), the landscape configuration is related to a curved shape associated with the basic meaning of roll ('turn over and over and move in a particular direction'): an imaginary sinusoid which is travelled by a(ny) point on the circumference of a circular object rolling along a straight line. It is worth noting that the same type of curve underlies the meaning of undulate, where the connection between the manner of motion and the path shape is fairly straightforward.

\footnotetext{
${ }_{16}$ 'To walk around slowly in a relaxed way or without any clear purpose or direction' (CALD).

17 Classified as a motion verb on the basis of uses like I eased my way towards the door (COBUILD).

18 This applies also to actual motion, e.g. Large numbers of refugees continue to flow from the troubled region into the no-man's land (COBUILD).
} 
For example, a swimmer using the undulating ${ }^{19}$ technique is seen as moving along a sinusoidshaped path aligned with his/her own body at any given moment. Similarly, an undulating road is automatically visualized in terms of sag and crest curves. Roll, by contrast, does not encode any specific path shape (cf. (14d) above) - which also explains the difference in classification.

In Slovene, the specifics of the path need to be expressed verb-externally. An exception in this respect is a zigzag path; however, the majority of FM expressions use the adverb cikcakasto in a zigzag pattern' (16b) instead of the verb cikcakati 'zigzag' (16a):

(16) a) Steza spet postane bolj strma in začne cikcakati preko rušnatega pobočja. (sITenTen) 'The path becomes steeper again and starts zigzagging across the grassy slope.'

b) Pot se cikcakasto in strmo spušča navzdol in res gre zelo hitro. (FidaPLUS v2)

'The zigzag path descends steeply and it really goes pretty fast.'

Examples (17a-b) illustrate the FM uses of snake and undulate. Slovene employs other means to express the respective meanings. In $(17 \mathrm{c})$, the basic-shape manner-of-motion verb viti se 'wind' is combined with the adverb kačasto 'like a snake'. In (17d), the upward/downward motion verbs vzpenjatilspǔšati ('ascend/descend') are combined with the adverbs strmo 'steeply' and nenehno 'continuously'.

(17) a) The road snakes through the hills, bend after bend, and it's time to try "race" mode. (ukWaC)

b) The road is undulating as it crosses various small hills and ridges left behind by the glaciers. (ukWaC)

c) Cesta se kačasto vije do visoko ležečih vasi. (FidaPLUS v2)

'The road, like a snake, winds its way up to the villages nestling in the hills.'

d) Cesta se nenehno strmo vzpenja in strmo spǔša. (FidaPLUS v2)

'The road keeps ascending steeply and descending steeply.'

The most frequent constituent conveying path-related information is an adverbial adjunct in the form of an adverbial or prepositional phrase. Another elegant possibility is an adjectival modifier. Sentence (18) below employs both: the adjective kačast 'having the shape of a snake' is fortuitously complemented by the cognate expression kot piton 'like a python' in adjunct function:

(18) Kačasta cesta se vije po pobočju kot piton. (FidaPLUS v2)

'The serpentine path winds its way up the slope like a python.'

In a similar manner, adjuncts and modifiers in Slovene FM constructions substitute for the meaning components of English verbs that pertain to actual motion, but are mapped onto specific features of the path. A case in point is steepness, which is implicit in the meanings of vertical motion verbs like plunge or soar. Slovene FM constructions use verbs with less specific meanings (cf. rise, fall) and combine them with adverbial or adjectival descriptions pertaining to the gradient.

19 Recognized as a technical term in swimming. 
(19) a) Na vzhodni strani se gora precej strmo spušča v dolino. (slTenTen)

'The east side of the mountain descends quite steeply into the valley.'

b) Od jezera se na tri strani dvigajo strme gore. (FidaPLUS v2)

'From the lake, steep mountains rise in three directions.'

c) Njena pobočja se dvigajo skoraj navpično. (FidaPLUS v2)

'Its slopes rise almost vertically.'

d) Njuno vzhodno pobočje pada globoko v dolino Možnice. (FidaPLUS v2)

'Their eastern slope falls deep into the Možnica valley.'

e) Proti zahodu se pobočje Raduhe spusti tako rekoč prepadno. (siTenTen)

'Towards the west the Raduha slope falls away almost precipitously.'

f) Steza skozi gozd se hitro spušča. (slTenTen)

'The path through the forest descends quickly.'

(19f) differs from the rest of the examples in that the gradient is expressed indirectly as the result of speed-to-path mapping: the high-speed component of the adverb hitro ('quickly') is mapped onto the steepness of the terrain. A parallel can be found in (20a) below, with the low-speed component of pocasi ('slowly') mapped onto the gentle curves of the road. The role of pocasi ('slowly') in the description of the road shape is comparable to that of blago ('gently') in (20b):

(20) a) Široka cesta počasi vijuga proti Veliki dolini. (FidaPLUS v2)

'The wide road winds slowly in the direction of Velika dolina.'

b) Cesta je blago vijugala med grički. (FidaPLUS v2)

'The road wound gently among the hillocks.'

It follows from the discussion that Slovene FM constructions rely heavily on verb-external means to describe the properties of the path. Nonetheless, adjuncts and modifiers are employed by English constructions as well; in fact, they are also found together with verbs whose meanings are specific enough to enable metonymic mapping. In (21) below, for example, the adjunct further specifies the gradient, a property already implicit in the meaning of the verb:

(21) In the south the mountains plunge vertically into the sea. (ukWaC)

The sentence offers some possibilities for further research, focusing on the role of adjuncts and modifiers in the two languages. Differences can be expected since a verb with metonymic potential makes redundant an adjunct/modifier whose meaning coincides with the meaning expressed by the verb itself (compare plunge ?steeply and plunge vertically). Another related and undoubtedly appealing topic is the metonymic use of adjuncts/modifiers whose manner-of-motion components are mappable onto path properties. Next, the aspectual variants of the Slovene verbs call for a contrastive study on the role of aspect in fictive motion. Last but not least, it follows from the discussion that FM expressions pose several challenges to translation. Rojo and Valenzuela (2003) report informational differences between translating real motion and fictive motion. Stošić and Sarda (2009) question the translational equivalence between fictive motion and posture verbs, 
arguing that translating fictive motion changes the conceptualization of the scene. They express the need for more contrastive studies which would help "define cross-linguistically the place of fictive motion in the expression of static scenes" (Stošić and Sarda 2009, 52).

\section{Conclusion}

English and Slovene differ in the scope of motion verbs conveying path-related information in FM expressions. Both employ directional and manner-of-motion verbs, but their number is considerably smaller in Slovene. The inventory of Slovene verbs includes lexical aspectual variants of directional verbs but lacks equivalents of many English verbs, including those resulting from noun-to-verb conversion. The meanings of English verbs are more specific, displaying components that can be mapped onto certain properties of the path. Besides the obvious correlations in terms of the direction/manner of motion and the path orientation/shape, the following metonymic mappings have been identified, with possible interplay between them: speed $\rightarrow$ gradient, speed $\rightarrow$ shape, unsteadiness $\rightarrow$ height, effortlessness $\rightarrow$ terrain configuration. In Slovene FM expressions, these properties need to be expressed verb-externally. The findings call for a study addressing such contrastive differences from the point of view of translation strategies that can be adopted when rendering fictive motion from English to Slovene, and vice versa.

\section{References}

Barcelona, Antonio. 2011. "Reviewing the Properties and Prototype Structure of Metonymy." In Defining Metonymy in Cognitive Linguistics: Towards a Consensus View, edited by Réka Benczes, Antonio Barcelona and Francisco José Ruiz de Mendoza Ibáñez, 7-58. Amsterdam: John Benjamins.

Egorova, Ekaterina, Thora Tenbrink, and Ross S. Purves. 2018. "Fictive Motion in the Context of Mountaineering.” Spatial Cognition \& Computation, 1-26. https://doi.org/10.1080/13875868.2018.143 1646.

Fauconnier, Gilles. 1994. Mental Spaces: Aspects of Meaning Construction in Natural Language. Cambridge, UK: Cambridge University Press.

—. 1997. Mappings in Thought and Language. Cambridge, UK: Cambridge University Press.

Fauconnier, Gilles, and Mark Turner. 2002. The Way We Think: Conceptual Blending and the Mind's Hidden Complexities. New York: Ingram Publisher Services US.

Jackendoff, Ray. 1994. Patterns in the Mind. Language and Human Nature. New York: Basic Books.

Jiménez Martínez-Losa, Noelia. 2007. “Towards a Typology of Fictive Motion Events: Review of Existing Proposals and Presentation of New Perspectives." Interlinguistica 17: 562-69.

Lakoff, George. 1987. Women, Fire, and Dangerous Things. Chicago and London: The University of Chicago Press.

Lakoff, George, and Mark Johnson. 2003. Metaphors We Live By. 2nd ed. London: University of Chicago Press.

Langacker, Ronald W. 1987. Foundations of Cognitive Grammar, Vol. 1: Theoretical Prerequisites. Stanford:

Stanford University Press.

-. 2000. Grammar and Conceptualization. Berlin and New York: Mouton de Gruyter.

Matlock, Teenie. 2004a. “Fictive Motion as Cognitive Simulation.” Memory \& Cognition 32 (8): 1389-1400.

—. 2004b. "The Conceptual Motivation of Fictive Motion." In Studies in Linguistic Motivation, edited by Günter Radden and René Dirven, 221-48. Berlin: Mouton de Gruyter. 
Matsumoto, Yo. 1996. “Subjective Motion and English and Japanese Verbs.” Cognitive Linguistics 7 (2): $183-226$.

Panther, Klaus-Uwe, and Linda L. Thornburg. 2005. "The Role of Conceptual Metonymy in Meaning Construction." In Cognitive Linguistics: Internal Dynamics and Interdisciplinary Interaction, edited by F. J. Ruiz de Mendoza Ibáñez and S. Peña Cervel, 353-86. Berlin and New York: Mouton de Gruyter.

Rojo, Ana, and Javier Valenzuela. 2003. "Fictive Motion in English and Spanish.” International Journal of English Studies 3 (2): 123-50.

—. 2010. "Fictive Motion in Spanish: Travellable, Non-Travellable and Path-Related Manner Information.” In Trends in Cognitive Linguistics: Theoretical and Applied Models, edited by Javier Valenzuela, Ana Rojo and Cristina Soriano, 244-60. Frankfurt am Main: Peter Lang.

Ruppenhofer, Josef. 2006. “Fictive Motion: Construction or Construal?” BLS 32 (1): 307-19. https://doi. org/10.3765/bls.v32i1.3470.

Stošić, Dejan, and Laure Sarda. 2009. “The Many Ways To Be Located in French and Serbian: the Role of Fictive Motion in the Expression of Static Location." In Space and Time in Language and Literature, edited by Marija Brala Vukanović and Lovorka Gruić Grmuša, 39-60. Newcastle upon Tyne: Cambridge Scholars Publishing.

Takemoto, Masashi. 2010. "Manner-of-Motion Verbs and Subjectification." Journal of Cross-Cultural Studies 4: $15-26$.

Talmy, Leonard. 2000. Toward a Cognitive Semantics. Vol. 1. Cambridge, Mass: MIT Press.

Waliński, Jacek Tadeusz. 2015. "Instrumentality of Fictive Motion in Coextension Paths.” Kwartalnik Neofilologiczny 62 (1): 87-101.

\section{Corpora}

BNC (British National Corpus) <https://the.sketchengine.co.uk/>

ukWaC (British English Corpus) <https://the.sketchengine.co.uk/>

enTenTen (English Web Corpus) < https://the.sketchengine.co.uk/>

FidaPLUS v2 (Slovenian Reference Corpus) <https://the.sketchengine.co.uk/>

slTenTen (Slovenian Web Corpus) <https://the.sketchengine.co.uk/>

\section{Dictionaries}

Cambridge Dictionary (the Cambridge Advanced Learner's Dictionary (CALD)) <https://dictionary. cambridge.org/>

Collins Dictionary (the COBUILD Advanced English Dictionary) <https://www.collinsdictionary.com/>

Oxford Learner's Dictionaries (the Oxford Advanced Learner's Dictionary (OALD)) <https://www. oxfordlearnersdictionaries.com/>

SSKJ. Slovar slovenskega knjižnega jezika <https://fran.si/130/sskj-slovar-slovenskega-knjiznega-jezika > 